Revue bibliographique pour le domaine irano-aryen

\title{
Michael Shenkar. "Images of Daēnā and Mithra on two seals from the Indo-Iranian borderlands"
}

\section{Olivia Ramble}

\section{Q OpenEdition}

1 Journals

\section{Édition électronique}

URL : http://journals.openedition.org/abstractairanica/43730

DOI : 10.4000/abstractairanica.43730

ISBN : 1961-960X

ISSN : 1961-960X

Éditeur :

CNRS (UMR 7528 Mondes iraniens et indiens), Éditions de l'IFRI

\section{Référence électronique}

Olivia Ramble, « Michael Shenkar. "Images of Daēnā and Mithra on two seals from the Indo-Iranian borderlands" », Abstracta Iranica [En ligne], Volume 37-38-39 | 2018, document 11, mis en ligne le 30 décembre 2018, consulté le 28 septembre 2020. URL : http://journals.openedition.org/ abstractairanica/43730 ; DOI : https://doi.org/10.4000/abstractairanica.43730

Ce document a été généré automatiquement le 28 septembre 2020.

Tous droits réservés 


\title{
Michael Shenkar. “Images of Daēnā and Mithra on two seals from the Indo-Iranian borderlands"
}

\author{
Olivia Ramble
}

\section{RÉFÉRENCE}

Michael Shenkar. "Images of Daēnā and Mithra on two seals from the Indo-Iranian borderlands", Studia Iranica, 44, 2015, p. 99-117.

1 L'A. identifie la Daēnā et Mithra respectivement sur deux sceaux de la collection d'Aman Ur Rahman (Ur Raman \& Falk 2011). Le premier, de forme conoïde typiquement sassanide, représenterait la Daēnā accueillant deux âmes (un père et son fils ?) dans l'au-delà, et accompagnée de deux chiens qui sont un attribut avestique de la déesse (Vd. 19.30). L'étrange habit court et transparent des deux figures pourrait évoquer la nudité des âmes (cf. les ossuaires sogdiens) ou leur état de mēnōg. Enfin, la coiffure bactrienne des personnages indique une facture kushano-sassanide. Le second sceau montrerait Mithra sur son char solaire, motif établi de son iconographie, bien qu'il n'arbore pas ici son auréole à rayons distinctive mais un simple nimbe, variation que l'A. explique par la facture fruste du sceau. L'inscription kharoshtī, « d'Arjun », évoque à l'A. le nom d'un des premiers rois Pārata, une dynastie (Balouchistan pakistanais, 125-300 de n. ère) dont plusieurs noms théophores suggèrent une forte association avec le culte de Mithra. Ces indices conduisent l'A. à dater le sceau de 150 à 200 de n. ère. 


\section{AUTEURS}

OLIVIA RAMBLE

Doctorante EPHE, Mondes iranien et indien, Paris 